\title{
Growth and morphometric relationships of the bean clam Donax punctatostriatus Hanley, 1843 in a sandy beach of southern Sinaloa, Mexico
}

\author{
Eduardo Ríos-Jara ${ }^{1}$, María del Carmen Esqueda-González ${ }^{1}$, Jesús Emilio Michel-Morfin² \\ Ernesto López-Uriarte ${ }^{1}$ \& José Salgado-Barragán ${ }^{3}$ \\ ${ }^{1}$ Departamento de Ecología, Centro Universitario de Ciencias Biológicas y Agropecuarias \\ Universidad de Guadalajara, Zapopan, Jalisco, México \\ ${ }^{2}$ Departamento de Estudios para el Desarrollo Sustentable de Zonas Costeras \\ Centro Universitario de la Costa Sur, Universidad de Guadalajara, San Patricio-Melaque \\ Jalisco, México \\ ${ }^{3}$ Instituto de Ciencias del Mar y Limnología, Unidad Académica de Mazatlán, Sinaloa, México \\ Corresponding author: María del Carmen Esqueda-González (carmen.esqueda@academicos.udg.mx)
}

\begin{abstract}
There have been no published studies of the genus Donax in the eastern tropical Pacific. This work describes the morphometric relationships, growth and mortality of the bean clam Donax punctatostriatus Hanley, 1843 in the sandy beach of Isla de la Piedra, south of Mazatlán Bay, Mexico. Direct collections by hand were performed during 20 monthly sample periods (November 2008 to June 2010) in the intertidal zone of the beach. A total of 2,324 clams of different sizes were removed from the sand, then measured and weighed in the laboratory. The length range of the shells was $2.78-25.64 \mathrm{~mm}$ (mean $=12.61 \pm 4.04 \mathrm{~mm})$. The length-weight relationship of the total sample indicated isometric growth $\left(a=0.0002 \mathrm{~g} ; b=3.0 \mathrm{~g} \mathrm{~mm}^{-1}, \mathrm{R}^{2}=0.97\right)$; there was positive allometric growth in the recruits $(<6.99 \mathrm{~mm})(b=3.4)$ and in juveniles $(b=3.2)$; in adults there was negative allometric growth $(b=2.6)$. Negative allometry of the length/width $(\log \mathrm{Wd}=-0.239+0.922 \log \mathrm{L})$ and height/width $(\log \mathrm{Wd}=-0.054+0.900 \log \mathrm{H})$ ratio of adults is consistent with a more compressed form of their shell, which assists rapid burying behavior in the sand. The maximum-recorded size of an empty shell (39 $\mathrm{mm}$ ) was used to set the value of $\mathrm{L}_{\infty}$ and to estimate K with the Shepherd (SLCA) method. The average growth rate during the life cycle was $0.43 \mathrm{~mm} \mathrm{yr}^{-1}$. Values of $\mathrm{L}_{\infty}$ between 29.16 and $34.22 \mathrm{~mm}$ were estimated with the Powell-Wetherall method using different class intervals. The mortality coefficient estimated with various methods was variable (0.84-1.15 $\left.\mathrm{yr}^{-1}\right)$. The growth of the clam is rapid and the mortality high, probably because of the characteristics of the habitat, in a subtropical region with high hydrodynamics and sediment transport.
\end{abstract}

Keywords: Bivalvia; bean clam; sizes; population dynamics; Von Bertalanffy growth model; Mexican Pacific

\section{INTRODUCTION}

Members of the genus Donax are commonly found on the high-energy sandy beaches of tropical and temperate regions (Ansell, 1983; Sastre, 1984; Nel et al., 2001; Gaspar et al., 2002a; Laudien et al., 2003). Due to the shape of their shell and well-developed foot, they can burrow easily and quickly into the sand in order to avoid being removed by the waves and currents (McLachlan et al., 1995; De la Huz et al., 2002). Some species of Donax frequently form part of the dominant macrofauna of sandy beach communities, with a low diversity of species (Ramón et al., 1995) due to the uns- table conditions (Gaspar et al., 2002a). These clams have an important ecological function because, as very active diggers, they can affect the sediment stability and availability of oxygen, contributing to the regulation of the dynamic and vertical distribution of the infauna (Jaramillo et al., 2007). Their activity as suspension filter feeders produces feces and pseudo-feces that increase the organic material content of the sediment, facilitating the presence of infaunal biota in this habitat (Levinton, 2001; Jaramillo et al., 2007).

The bean clam Donax punctatostriatus Hanley, 1843 (Bivalvia: Donacidae) presents a geographic distribution that ranges from Isla de Cedros, in Baja

Corresponding editor: Claudia Bremec 
California Sur $\left(28^{\circ} \mathrm{N}\right)$ and Laguna San Ignacio, in the Gulf of California, to Manzanillo, Colima $\left(19^{\circ} \mathrm{N}\right)$. Its bathymetric distribution ranges from the intertidal zone to a water depth of $17 \mathrm{~m}$ (Coan \& Valentich-Scott, 2012). On the sandy beaches of Isla de la Piedra, Mazatlán, D. punctatostriatus is the dominant species together with the anomurous crustacean Emerita ratbunae, which is the dominant species for most of the year and serves as a prey item for marine and terrestrial predators although it is little used by local populations. While this clam is of little commercial interest and is rarely consumed, it used locally to make handcrafts.

Studies related to the population structure of species of the genus Donax have focused on the evaluation of their biometric relationships, growth and mortality (Rhoads \& Pannella, 1970; Neuberger-Cywiak et al., 1990; Gaspar et al., 2002a,b). The main environmental factors that influence the morphometry of the shell of Donax species include sediment type (Nel et al., 2001; De la Huz et al., 2002), exposure to waves, water depth, currents, tidal regime, temperature and salinity (Newell \& Hidu, 1982; Neuberger-Cywiak et al., 1990; Levinton, 2001; Gaspar et al., 2002b). However, in the Mexican Pacific, biological and ecological knowledge of these species is null, for which reason determination of the growth rate and biometric relationships of $D$. punctatostriatus will contribute to a fuller understanding of the biotic (endogenous, physiological) and abiotic (exogenous) factors that influence the morphology and population dynamics of this clam in this region of the world.

According to Gaspar et al. (2001), estimates of the length-weight relationship of $D$. trunculus, $D$. semistriatus and $D$. variegatus from the southern coast of Portugal indicate that the latter two species have positive allometric growth, while in $D$. trunculus is negative allometric. These authors suggest that the species of this genus present opposite growth types because of their different bathymetric distribution. Gaspar et al. (2002a) report inter-specific morphometric differences among Donax species: D. trunculus presents negative allometric growth in both length/height $(\mathrm{L} / \mathrm{H})$ and length/width $(\mathrm{L} / \mathrm{Wd})$ relationships; D. semistriatus has positive allometry in $\mathrm{L} / \mathrm{H}$ and isometry in $\mathrm{L} / \mathrm{Wd}$ while $D$. variagatus has negative allometry in $\mathrm{L} / \mathrm{H}$ and positive in $\mathrm{L} / \mathrm{Wd}$. According to these authors, negative allometry can be attributed to their distribution in shallow waters. D. trunculus has a compressed shell with a smooth surface, which helps to function as an active and efficient digger, which prevents the clams from being extracted from the beach sediment by the waves and currents (De la Huz et al., 2002; Gaspar et al., 2002a).
Different direct and indirect methods have been used to estimate the growth rate in donacids. Direct methods are based on the size of clams measured between consecutive observable events. This method implies taking direct measurements of particular individuals and extrapolating the results to the entire population. This method has been conducted in populations of $D$. trunculus from the west coasts of Israel (Neuberger-Cywiak et al., 1990), from the Mediterranean coast of Spain (Ramón et al., 1995), and the southern coast of Portugal (Gaspar et al., 1999). Also, with $D$. dentifer in the bay of Malaga, Colombia (Riascos \& Urban, 2002), with D. serra on the coast of Namibia (Laudien et al., 2003) and with D. hanleyanus in Mar de Las Pampas, Argentina (Herrmann et al., 2009).

The indirect methods are based on the analysis of groups (cohorts) of individuals of approximately similar sizes. These methods have been used in populations of $D$. trunculus on the coast of Spain (Mazé \& Laborda, 1990; De la Huz et al., 2002), D. variabilis roemeri in Veracruz, Mexico (Belmar-Pérez \& Guzmán del Próo, 1997), D. denticulatus at Isla Margarita, Venezuela (Marcano et al., 2003) and D. obesulus on the coast of Peru (Aguirre-Velarde \& Mendo-Aguilar, 2008). The results of these studies show important differences according to each population and region, even when it is the same species.

The present study describes morphometric relationships, growth parameters $\left(\mathrm{K}, \mathrm{L}_{\infty}\right)$ and mortality rate in a population of $D$. punctatostriatus from the sandy beach of Isla de la Piedra, located to the south of Mazatlán, Mexico. The research was conducted in order to generate information that contributes to understanding important aspects of the biology and ecology of this clam. In addition, these results may be used in future studies on the dynamics of other populations of this species along with its geographic distribution.

\section{MATERIALS AND METHODS}

\section{Study area}

The Isla de La Piedra is a peninsula with an extensive sandy beach located to the south of the port of

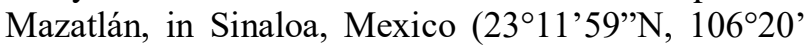
$19^{\prime \prime W}$ ) at the Gulf of California (Fig. 1). During 20 months (November 2008 to June 2010), clams were collected directly from the sand by excavating to approximately $30 \mathrm{~cm}$ in depth with a hand shovel. This clam has been observed in Isla de La Piedra throughout the year and has vertical migrations in shallow intertidal and subtidal environments (Esqueda-González et 


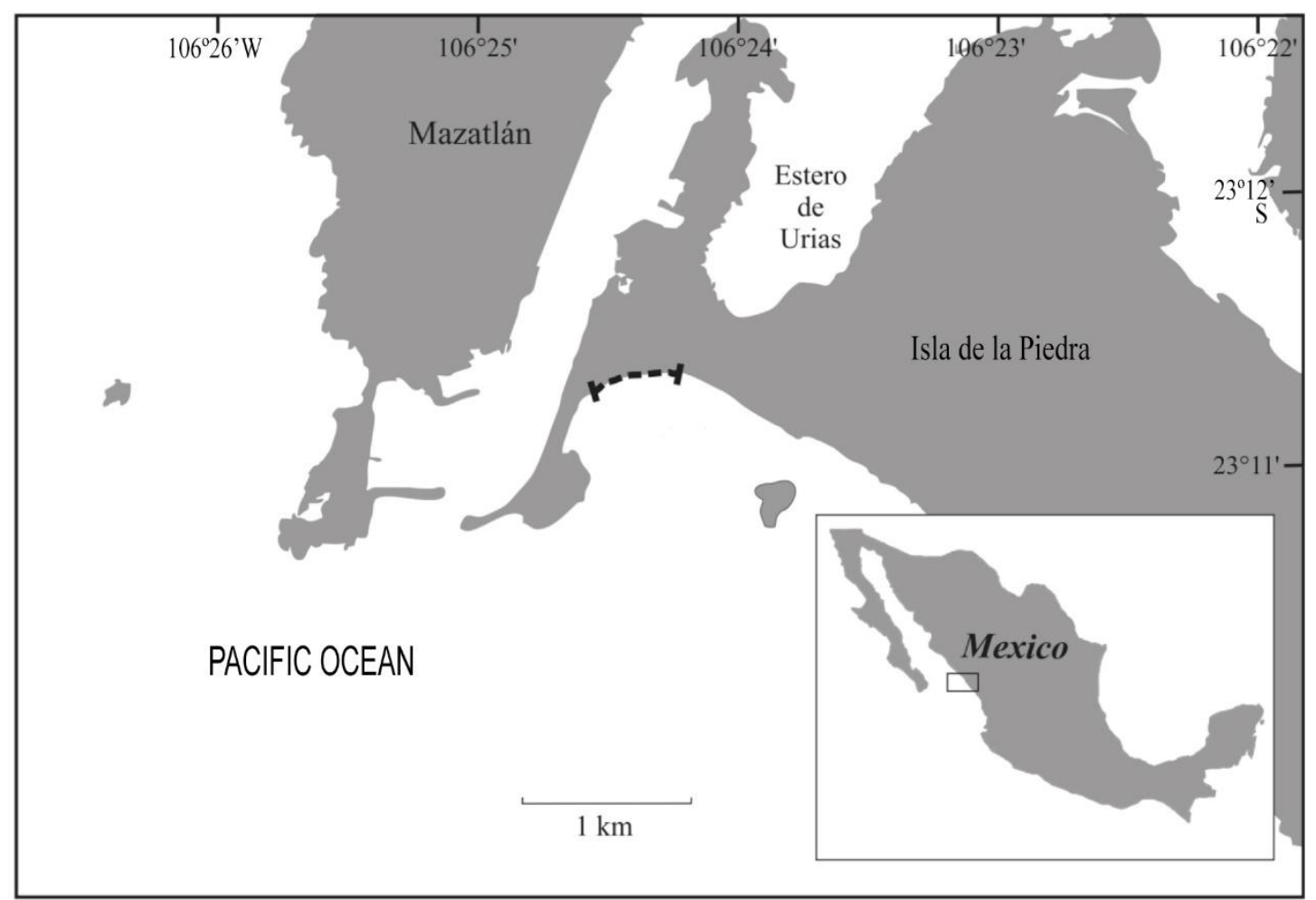

Figure 1. The study area (dotted line) where the bean clam Donax punctatostriatus survey was conducted on Isla de La Piedra, México.

al., 2018). The sample size was between 45 and 219 ind month $^{-1}$, except in the months where there was a great disproportion of organisms towards smaller sizes as a result of recruitment; in those months, a subsample of $25 \%$ of the recruits was taken in order to estimate their abundance and sizes. Subsequently, all samples were standardized to 50 individuals through the maximum relative error method (Sparre \& Venema, 1995): $\varepsilon=t_{\mathrm{n}}$ $-1 \times s / \bar{x} \times \sqrt{\bar{x}}$, where $\varepsilon$ is the relative maximum error, $t_{\mathrm{n}}-1$ are the degrees of freedom of the Student $t$ distribution, $s$ is the standard deviation of the sample, $\bar{x}$ is the mean of the sample and $n$ is the number of clams.

\section{Laboratory work}

Shell length (the maximum distance on the anteriorposterior axis) was determined using a digital Vernier caliper (accurate to $\pm 0.01 \mathrm{~mm}$ ). Total weight was measured with an analytical balance (accurate to $\pm 0.001 \mathrm{~g}$ ). For the growth analysis, $77 \%$ of the clams were selected and shell height (the maximum distance on the dorsal and ventral axis, across the shell middle axis) and width (the maximum distance on the lateral axis between both valves of the closed-shell) measured. The rest of the clams (23\%) were used to study their reproductive cycle (Esqueda-González et al., 2018).
Also, a large number of juveniles were observed in July 2009 , whereby a subsample of $25 \%$ of the individuals of between 3.0 and $7.0 \mathrm{~mm}$ in length was taken.

\section{Data analysis}

Size frequency distribution and recruitment. Histograms of a monthly size-frequency distribution (class intervals $=1 \mathrm{~mm}$ ) were constructed for the entire study period. The data were then grouped in order to obtain the distribution of the total number of individuals. The central tendency values and coefficient of variation $(\mathrm{CV}=($ standard deviation $/$ mean $) \times 100)$ were obtained, with the latter considered an indicator of recruitment, where high values indicate large size intervals relative to the mean and therefore the possibility of frequent recruitment (Ebert, 1988).

Morphometric relationships. The criterion of Ocaña \& Fernández (2011) was followed to separate the recruits and juveniles. According to this criterion, these groups are recognized by the variation in the growth pattern using the relationships length-height, lengthwidth and height-width. The above was done by separating the clams in class intervals of one millimeter. The length-weight relationship was estimated considering: a) the total number of individuals, b) 
adults, c) juveniles and d) recruited individuals, using the equation proposed by Le Cren (1951):

$$
\mathrm{W}_{(\mathrm{i})}=a \times \mathrm{L}_{(\mathrm{i})} b
$$

where $\mathrm{W}_{(\mathrm{i})}=$ total weight $(\mathrm{g}), \mathrm{L}_{(\mathrm{i})}=$ length $(\mathrm{mm}), a=$ intercept (coefficient of initial growth) and $b=$ slope (coefficient of growth, i.e. relative growth rate of the variables).

For analysis of the morphometric relationship's length-height, length-width and height-width, only adult individuals ( $\mathrm{L} \geq 12 \mathrm{~mm}$ ) were considered, and fits were made corresponding to a linear function (Ricker 1973; Laws \& Archie, 1981):

$$
\log \mathrm{y} \mathrm{Y}=\log a+b \log \mathrm{X}
$$

where $\mathrm{Y}=$ height $(\mathrm{H})$ or width $(\mathrm{Wd}) ; \mathrm{X}=$ length $(\mathrm{L}) ; a$ $=$ intercept or coefficient of initial growth and $b=$ slope or relative growth rate of the variables.

The coefficient of allometry is expressed by the exponent $b$ in the linear regression equations. In these equations, both measurements are linear and are expressed using the same units, where $b=1$ (isometric relationship) and, in the relationship length-weight, the exponent $b=3$ describes an isometric growth. The parameters $a$ and $b$ of the biometric relationships were estimated using linear regression analysis and the leastsquares method. The degree of association among variables was calculated using the determination coefficient $\left(\mathrm{R}^{2}\right)$, and ANOVAs were performed in order to determine the $95 \%$ confidence intervals to $b$ and the level of $\mathrm{R}^{2}$ significance. In order to determine whether the values of $b$ obtained with the linear regressions were significantly different to the isometric values $(b=1$ or $b=3)$, and to establish whether there is a negative ( $b<$ 1 or $b<3)$ or positive $(b>1$ or $b>3)$ allometric relationship, a $t$-test (Ho: $b=1$ or Ho: $b=3$ ) was performed, with levels of significance of $\pm 95 \%(\alpha=$ 0.05) (Sokal \& Rohlf, 1995).

\section{Growth and mortality}

The growth parameters $L_{\infty}$ and $K$ of the Von Bertalanffy equation were calculated using various analysis routines contained in the software FiSAT II (Fish Stock Assessment Tools II) (Gayanilo et al., 2005). These methods included: a) an electronic analysis of size frequencies (ELEFAN I), b) a Shepherd size composition analysis (SLCA), and c) the method of Powell-Wetherall. For each of the analyses, growth parameters were estimated with three different class intervals (1, 2 and $4 \mathrm{~mm})$. In addition, the data were smoothed using moving average (order 3 ).

The coefficient of total mortality $(\mathrm{Z})$ was estimated using the methods of Ault \& Erhardt (1991) and Beverton \& Holt (1956), as well as that of Pauly (software FiSAT II ${ }^{\circledR}$ ) (Gayanilo et al., 2005). Donax punctatostriatus is not locally exploited, for which reason $\mathrm{Z}$ is assumed to be equal to natural mortality (M). The sex ratio of this population does not differ significantly from +1 1: $1 \overbrace{}^{\Uparrow}$ (Esqueda-González et al., 2018); therefore the entire population was evaluated with no separation of the sexes.

\section{RESULTS}

\section{Size frequency distribution and recruitment}

The length of the clams considered in the analysis was 2.78 to $25.64 \mathrm{~mm}($ mean $=12.61 \pm 4.04 \mathrm{~mm})$. Of the total number of clams $(2,324), 159$ were recruited $(2.78$ to $6.99 \mathrm{~mm}$ ), 959 were juveniles ( 7.0 to $11.99 \mathrm{~mm}$ ), and 1,206 were adults (12.0 to $25.64 \mathrm{~mm}$ ) (Table 1, Fig. 2). Clam recruitment occurred throughout the sampling period, but at a higher frequency in the periods April to September $2009(\mathrm{CV}=29.5-34.6 \%)$ and March to June $2010(\mathrm{CV}=24.2-31.3 \%)$. Lower frequencies of recruitment were presented in December 2008, February to March 2009 and January and May 2010 (Fig. 3).

\section{Morphometric relationships}

The length-weight relationship obtained from the sample presented a value of $a=0.0002 \mathrm{~g}$ and $b=3.0 \mathrm{~g}$ $\mathrm{mm}^{-1}\left(\mathrm{R}^{2}=0.97\right)$, indicating isometric growth (Table $2)$. The recruited and juvenile clams presented positive allometric growth $\left(b=3.4\right.$ and 3.2 , respectively) $\left(\mathrm{R}^{2}=\right.$ 0.84 and 0.91 , respectively), while negative allometric growth was found in the adults $\left(b=2.6 ; \mathrm{R}^{2}=0.94\right)$. Height or width increases at a slower rate than length hence the negative allometry of the $\mathrm{L} / \mathrm{Wd}$ and $\mathrm{L} / \mathrm{H}$ relationships). In the case of the 841 adult clams, the student $\mathrm{t}$-test indicates that the relationships $\mathrm{L} / \mathrm{W}$ and $\mathrm{H} / \mathrm{Wd}$ are negative allometric, and the relationship $\mathrm{L} / \mathrm{H}$ is isometric $(P<0.05)$ (Table 2$)$.

\section{Growth and mortality}

After considering the values of $\mathrm{L}_{\infty}$ and $\mathrm{K}$ of the Von Bertalanffy growth model obtained with the different

Table 1. The size distribution of the bean clam Donax punctatostriatus in Isla de La Piedra, Sinaloa, Mexico (Nov. 2008-Jun. 2010). SD: standard deviation.

\begin{tabular}{lcccr}
\hline Group & $\begin{array}{c}\text { Number of } \\
\text { individuals }\end{array}$ & $\begin{array}{c}\text { Range of } \\
\text { sizes }(\mathrm{mm})\end{array}$ & Mode & Mean \pm SD \\
\hline Total & 2,324 & $2.78-25.64$ & 11.0 & $12.61 \pm 4.04$ \\
Recruits & 159 & $2.78-6.99$ & 6.49 & $5.89 \pm 0.88$ \\
Juveniles & 959 & $7.0-11.99$ & 11.0 & $9.91 \pm 1.40$ \\
Adults & 1,206 & $12.0-25.64$ & 12.5 & $15.64 \pm 2.98$ \\
\hline
\end{tabular}




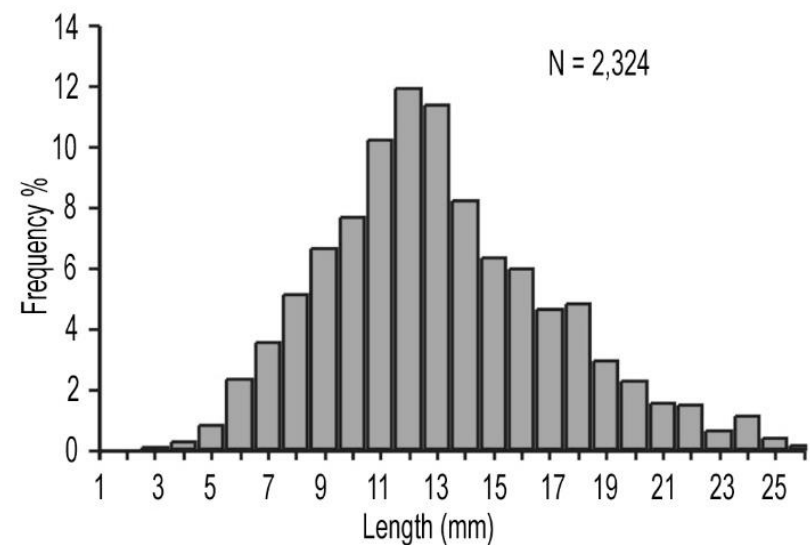

Figure 2. The size distribution of the number total of Donax punctatostriatus (November 2008 to June 2010) collected on Isla de La Piedra, Mexico.

methods, it was concluded that the Shepherd method presents the most consistent $\mathrm{K}$ values. From these values, it was determined that Donax punctatostriatus has a growth rate of $0.43 \mathrm{~mm} \mathrm{yr}^{-1}$. The maximum size, taken from an empty shell on Isla de La Piedra $(39 \mathrm{~mm})$, was used to fix the value of $\mathrm{L}_{\infty}$ and calculate $\mathrm{K}$ (Table $3)$. The asymptotic length was also estimated using the method of Powell-Whetherall, producing values of 29.16 to $34.22 \mathrm{~mm}$. After smoothing the data with a moving average of order 3 , this interval was 27.64 to $28.41 \mathrm{~mm}$. The values of mortality of this clam did not notably differ between the methods of Ault and Erhardt $\left(0.84 \mathrm{yr}^{-1}\right)$ and Pauly $\left(0.88 \mathrm{yr}^{-1}\right)$, but the value estimated using the method of Beverton and Holt $\left(1.15 \mathrm{yr}^{-1}\right)$ (Table 4) was considerably higher.

\section{DISCUSSION}

The present study represents the first exploration of growth in Donax punctatostriatus. The results of this study have been compared with those available for other species of Donax (Table 5). In D. punctatostriatus, the length-weight relationship was estimated for different age groups; positive allometry was recorded among pre-adults (recruited and juveniles), while negative allometry was found in adults' clam. The positive allometry in other species of Donax, in juvenile clams, has been associated with individuals that present a reduced capacity for successful burial and remain half-exposed in the sand with a great risk of displacement, especially in the intertidal zone, where the greatest wave activity occurs (Gaspar et al., 2001). The recruits show little variation in terms of shell form and, at this stage, it is highly likely that they will display more feeding activity related to their dispersion and mobility in the entire area swept by the tidal currents. The negative allometry ob-

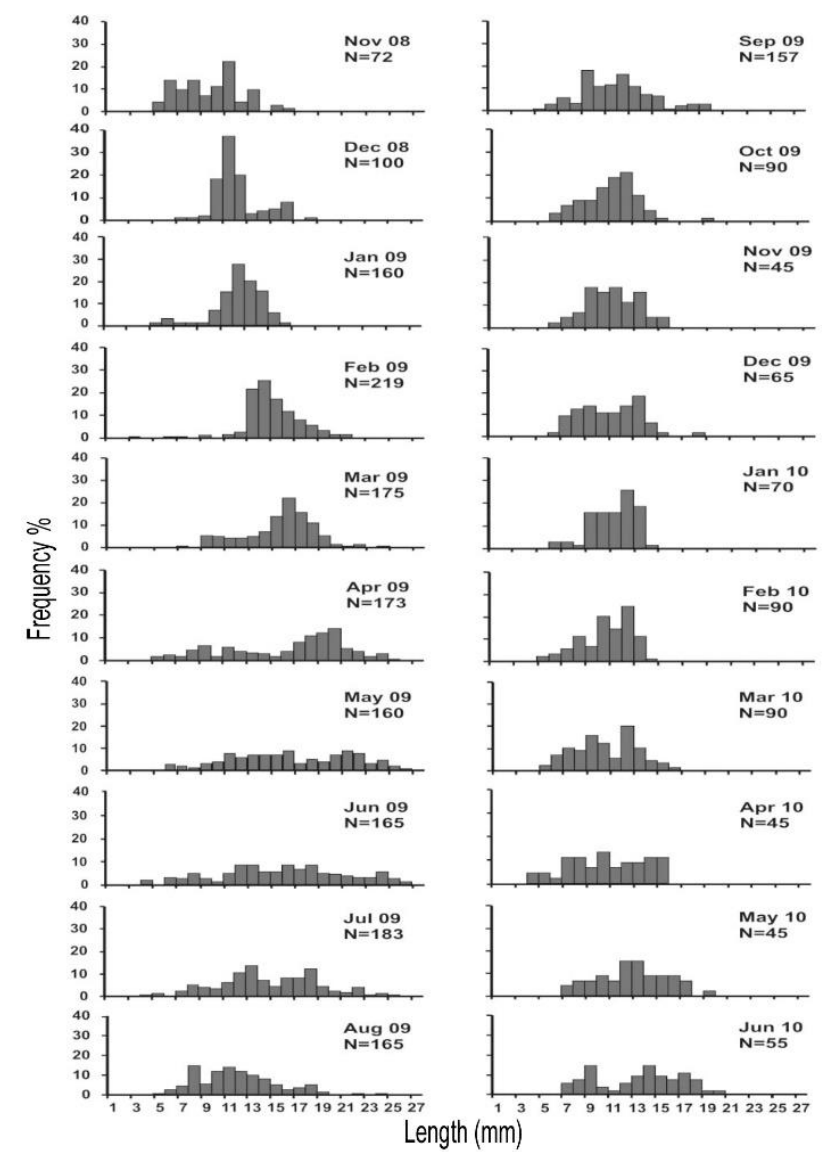

Figure 3. Monthly distribution of size frequencies of Donax punctatostriatus, collected on Isla de La Piedra, Mexico.

served in adult clams coincides with that observed in $D$. trunculus, but differs from that recorded in $D$. semistriatus and D. variegatus (Gaspar et al., 2001).

Juvenile and recruited clams were excluded from the analysis of the relationships $\mathrm{L} / \mathrm{H}, \mathrm{L} / \mathrm{W}$ and $\mathrm{H} / \mathrm{Wd}$; it was considered that inclusion of individuals of sizes $<12 \mathrm{~mm}$ could erroneously influence the estimates, since the shells of young clams present little tridimensional variation during this stage of growth, as demonstrated by the analysis of the biometric relationships of this size group. In some bivalves, the shell can be higher than it is wide at the start of its growth, which allows it to resist removal from the sediment by currents and turbulence (Hinch \& Bailey, 1988). However, the shell of the young and adult clams changes its proportions and morphometric with growth. These ontogenic changes in growth type have been related to different life habits; since the juveniles present shells that are more hydrodynamic, they are active diggers in the intertidal zone, while this ability to tunnel diminishes in the adults, favoring a more sedentary lifestyle, as reported in other Donax species (Thayer, 1975; Soares et al., 1996; Gaspar et al., 2002b; Ocaña \& Fernández, 2011). 
Table 2. Length-weight relationship and biometrical parameters of Donax punctatostriatus of Isla de La Piedra, Mexico. n: number of specimens, L: length $(\mathrm{mm})$, W: weight $(\mathrm{g}), \mathrm{H}$ : height $(\mathrm{mm})$, Wd: width $(\mathrm{mm})$, SD: standard deviation, CI: confidence intervals, ${ }^{*} P<0.05$. 1: total; 2 : recruits; 3 : Juveniles, and 4-5: adults.

\begin{tabular}{lllcll}
\hline $\begin{array}{l}\text { Biometric } \\
\text { relation }\end{array}$ & \multicolumn{1}{c}{$\mathrm{n}$} & Biometric equation & $\begin{array}{c}\text { Determination } \\
\text { Coefficient }\end{array}$ & SE of $b(95 \% \mathrm{CI})$ & $\begin{array}{l}\text { Relation } \\
(\mathrm{t} \text { test })\end{array}$ \\
\hline $\mathrm{L} / \mathrm{W}^{1}$ & 2,324 & $\mathrm{~W}=0.0002 \mathrm{~L}^{3.04}$ & $0.97^{*}$ & $0.01(3.019-3.059)$ & Isometric \\
$\mathrm{L} / \mathrm{W}^{2}$ & 159 & $\mathrm{~W}=0.00008 \mathrm{~L}^{3.43}$ & $0.84^{*}$ & $0.12(3.193-3.668)$ & Allometric + \\
$\mathrm{L} / \mathrm{W}^{3}$ & 959 & $\mathrm{~W}=0.0001 \mathrm{~L}^{3.28}$ & $0.91^{*}$ & $0.03(3.224-3.353)$ & Allometric + \\
$\mathrm{L} / \mathrm{W}^{4}$ & 1,206 & $\mathrm{~W}=0.0005 \mathrm{~L}^{2.66}$ & $0.94^{*}$ & $0.02(2.624-2.699)$ & Allometric - \\
$\mathrm{L}^{5}$ & 841 & $\log \mathrm{H}=-0.202+1.023 \log \mathrm{L}$ & $0.94^{*}$ & $0.009(1.005-1.041)$ & Isometric \\
$\mathrm{L} / \mathrm{Wd}^{5}$ & 841 & $\log \mathrm{Wd}=-0.239+0.922 \log \mathrm{L}$ & $0.84^{*}$ & $0.01(0.895-0.949)$ & Allometric - \\
$\mathrm{H} / \mathrm{Wd}^{5}$ & 841 & $\log \mathrm{Wd}=-0.054+0.900 \log \mathrm{H}$ & $0.93^{*}$ & $0.008(0.884-0.917)$ & Allometric - \\
\hline
\end{tabular}

Table 3. Estimations of the growth parameters and $\mathrm{K}$ $\left(\mathrm{yr}^{-1}\right.$ ) with maximum length $\mathrm{L}_{\infty}(\mathrm{mm})$ set to $39 \mathrm{~mm}$ for Donax punctatostriatus collected on Isla de La Piedra, Mexico. *Moving average order 3.

\begin{tabular}{cccc}
\hline \multicolumn{3}{c}{ Method } \\
\cline { 1 - 1 } \cline { 4 - 4 } Shepherd & \multicolumn{2}{c}{ Wetherall } \\
\cline { 1 - 1 } \cline { 4 - 4 }$\left(\mathrm{yr}^{-1}\right)$ & & $\mathrm{L}_{\infty}$ & $\mathrm{Z} / \mathrm{K}$ \\
\hline 0.430 & & 29.16 & 3.44 \\
$0.420^{*}$ & & 28.28 & $3.19^{*}$ \\
\hline
\end{tabular}

The regression of $\mathrm{L} / \mathrm{H}$ indicated isometric growth in adults. This growth type is attributed to donacid species that are distributed in shallow to deep water (Gaspar et al., 2002a), although in the case of $D$. punctatostriatus it corresponds to adult individuals that inhabit shallow water. In the intertidal zone of the beach at Isla de La Piedra, only juveniles and adults of small sizes (7.0$25.64 \mathrm{~mm}$ in length) were found. This is also the case with $D$. serra, which is distributed between the intertidal and shallow subtidal zones, especially on dissipative beaches (McLachlan, 1996).

The relationship $\mathrm{L} / \mathrm{Wd}$, as with that of $\mathrm{L} / \mathrm{W}$, presented negative allometric growth in $D$. punctatostriatus, indicating a trend towards enlargement of the shell, as has been associated with active burrowing bivalve species distributed in shallow waters. This allometry indicates that older shells are thinner in cross-section ( $\mathrm{L} / \mathrm{Wd}$ is negative allometric) but maintain a similar lateral outline ( $\mathrm{L} / \mathrm{H}$ is isometric). According to De la Huz et al. (2002), coarse sediments limit the presence of $D$. trunculus on exposed sandy beaches of the Iberian Peninsula. Because the capacity for burial among the bivalves that live in soft substrates depends on the particle size of that substrate (Newell \& Hidu, 1982), although the individuals that inhabit exposed beaches must bury themselves more rapidly in order to avoid physical removal from the substrate by the actions of the waves and tidal currents. In addition to limiting the distribution of clams such as Mya arenaria, substrates formed by coarse grains present a higher physical resis-
Table 4. Estimations of the natural mortality (M) of Donax punctatostriatus from Isla de La Piedra, Mexico.

\begin{tabular}{lc}
\hline Method & Natural mortality \\
\hline Ault \& Erhardt & 0.84 \\
Beverton \& Holt & 1.15 \\
Pauly & 0.88 \\
\hline
\end{tabular}

tance to burial (Newell \& Hidu, 1982). The predominance of small clams in the intertidal and large clams in the shallow subtidal zones has been related to intraspecific competition for food and space between the juveniles and adults of D. trunculus (Gaspar et al., 2002b).

The species of the genus Donax presented different growth types. The effect of sediment particle size on shell growth (positive or negative allometry) has been recognized in other bivalve species; the shape of the bivalve determines its capacity for penetration of the substrate, as is the case with Tellina tenuis, Macoma balthica, Donax vittatus and Cerastoderma edule (Trueman et al., 1966; Brown \& Trueman, 1991), Donax faba, D. serra, D. sordidus, D. hanleyanus, Mesodesma mactroides, Tivela stultorum and Siliqua patula (McLachlan et al., 1995; Nel et al., 2001; Fiori \& Carcedo, 2015), as well as Mactra violacea (Laxmilatha, 2008) and Ruditapes philippinarum (Caill-Milly et al., 2012). In this type of study, it is important to consider local environmental conditions (i.e., sediment type, exposure to waves, the incidence of currents), since these can differ markedly.

The Shepherd method using size-frequency distribution was found to be the most suitable for estimating growth in the population of D. punctatostriatus at Isla de La Piedra, since it produced estimates that were consistent with the different class intervals. In reality, the estimation of growth values from indirect methods based on the analysis of size-frequency distributions can be considered an advantage in this study. Such analysis is more precise when based on data obtained 
Table 5. Biometric relationships of species of the genus Donax. n: number of individuals, H: height $(\mathrm{mm})$, Wd: width (mm), L: length $(\mathrm{mm})$, W: weight $(\mathrm{g})$, min: L minimum, max: L maximum, SE: standard error, SD: standard deviation, CI: confidence intervals, NA: not available.

\begin{tabular}{|c|c|c|c|c|c|c|c|}
\hline $\begin{array}{l}\text { Species } \\
\text { (depth) }\end{array}$ & $\mathrm{n}$ & $\begin{array}{l}\mathrm{L} \text { mean } \pm \mathrm{SD} \\
(\min -\max )\end{array}$ & $\begin{array}{l}\text { Allometric } \\
\text { relationship }\end{array}$ & Allometric equation & $\begin{array}{c}\text { Determination } \\
\text { Coefficient }\left(\mathrm{R}^{2}\right)\end{array}$ & $\begin{array}{c}\text { SE of b } \\
(95 \% \text { CI of } b)\end{array}$ & $\begin{array}{l}\text { Relationship } \\
(t \text {-test) }\end{array}$ \\
\hline \multirow[t]{3}{*}{ Donax faba $(0 \mathrm{~m})^{1}$} & 13 & $(\mathrm{NA}-24)$ & $\mathrm{H} / \mathrm{L}$ & $\mathrm{H}=0.63 \mathrm{~L}+0.68$ & 0.97 & - & Allometric - \\
\hline & & & $\mathrm{Wd} / \mathrm{L}$ & $\mathrm{Wd}=0.37 \mathrm{~L}+0.54$ & 0.99 & - & Allometric - \\
\hline & & & $\mathrm{W} / \mathrm{L}$ & $\mathrm{W}=0.22 \mathrm{~L}^{2.89}$ & 0.99 & - & Allometric - \\
\hline \multirow[t]{3}{*}{ Donax serra $(0 \mathrm{~m})^{1}$} & 30 & (NA - 66) & $\mathrm{H} / \mathrm{L}$ & $\mathrm{H}=0.59 \mathrm{~L}-0.76$ & 0.97 & - & Allometric - \\
\hline & & & $\mathrm{Wd} / \mathrm{L}$ & $\mathrm{Wd}=0.42 \mathrm{~L}-3.48$ & 0.99 & - & Allometric - \\
\hline & & & $\mathrm{W} / \mathrm{L}$ & $\mathrm{W}=0.03 \mathrm{~L}^{3.37}$ & 0.99 & - & Allometric + \\
\hline \multirow[t]{3}{*}{ Donax sordidus $(0-5 \mathrm{~m})^{1}$} & 22 & (NA - 30) & $\mathrm{H} / \mathrm{L}$ & $H=0.62 L+1.89$ & 0.87 & - & Allometric - \\
\hline & & & $\mathrm{Wd} / \mathrm{L}$ & $\mathrm{Wd}=0.41 \mathrm{~L}-0.34$ & 0.94 & - & Allometric - \\
\hline & & & $\mathrm{W} / \mathrm{L}$ & $\mathrm{W}=0.23 \mathrm{~L}^{2.93}$ & 0.98 & - & Allometric - \\
\hline \multirow[t]{3}{*}{ Donax hanleyanus $(0 \mathrm{~m})^{1}$} & 47 & (NA - 24) & $\mathrm{H} / \mathrm{L}$ & $\mathrm{H}=0.63 \mathrm{~L}+0.26$ & 0.99 & - & Allometric - \\
\hline & & & $\mathrm{Wd} / \mathrm{L}$ & $\mathrm{Wd}=0.48 \mathrm{~L}-0.24$ & 0.97 & - & Allometric - \\
\hline & & & $\mathrm{W} / \mathrm{L}$ & $\mathrm{W}=0.11 \mathrm{~L}^{3.09}$ & 0.99 & - & Allometric + \\
\hline Donax variabilis roemeri ${ }^{-2}$ & - & (NA - 24) & $\mathrm{W} / \mathrm{L}$ & $\mathrm{W}=0.00047 \mathrm{~L}^{2.65}$ & - & - & Allometric - \\
\hline Donax semistriatus $^{3}$ & 255 & $\begin{array}{l}27.37 \pm 4.62 \\
(17.40-42.80)\end{array}$ & $\mathrm{W} / \mathrm{L}$ & $\mathrm{W}=0.00006 \mathrm{~L}^{3.17}$ & 0.92 & $0.057(3.06-3.28)$ & Allometric + \\
\hline Donax trunculus ${ }^{3}$ & 740 & $\begin{array}{l}27.25 \pm 5.52 \\
(16.00-44.00)\end{array}$ & $\mathrm{W} / \mathrm{L}$ & $\mathrm{W}=0.0006 \mathrm{~L}^{2.57}$ & 0.99 & $0.049(2.47-2.67)$ & Allometric - \\
\hline Donax variegatus ${ }^{3}$ & 164 & $\begin{array}{l}31.25 \pm 4.51 \\
(21.00-40.12)\end{array}$ & $\mathrm{W} / \mathrm{L}$ & $\mathrm{W}=0.00002 \mathrm{~L}^{3.37}$ & 0.94 & $0.064(3.25-3.50)$ & Allometric + \\
\hline Donax semistriatus $^{4}$ & 263 & $\begin{array}{l}27.31 \pm 4.58 \\
(17.40-42.80)\end{array}$ & $\begin{array}{c}\mathrm{H} / \mathrm{L} \\
\mathrm{Wd} / \mathrm{L}\end{array}$ & NA & $\begin{array}{l}0.93 \\
0.87\end{array}$ & $\begin{array}{l}0.018(1.015-1.085) \\
0.023(0.94-1.031)\end{array}$ & $\begin{array}{l}\text { Allometric + } \\
\text { Isometric }\end{array}$ \\
\hline Donax trunculus ${ }^{4}$ & 740 & $\begin{array}{l}27.25 \pm 5.52 \\
(16.00-44.00)\end{array}$ & $\begin{array}{c}\mathrm{H} / \mathrm{L} \\
\mathrm{Wd} / \mathrm{L}\end{array}$ & $\begin{aligned} \log \mathrm{H} & =-0.67+0.88 \log \mathrm{L} \\
\log W d & =-0.29+0.86 \log \mathrm{L}\end{aligned}$ & $\begin{array}{l}0.93 \\
0.92\end{array}$ & $\begin{array}{l}0.009(0.871-0.905) \\
0.009(0.848-0.884)\end{array}$ & $\begin{array}{l}\text { Allometric - } \\
\text { Allometric - }\end{array}$ \\
\hline Donax variegatus ${ }^{4}$ & 170 & $\begin{array}{l}30.94 \pm 4.77 \\
(13.00-40.12)\end{array}$ & $\begin{array}{r}\mathrm{H} / \mathrm{L} \\
\mathrm{Wd} / \mathrm{L}\end{array}$ & $\begin{aligned} \log H & =-0.25+0.93 \log L \\
\log W d & =-0.79+1.12 \log L\end{aligned}$ & $\begin{array}{l}0.91 \\
0.90\end{array}$ & $\begin{array}{l}0.023(0.895-0.984) \\
0.029(1.065-1.179)\end{array}$ & $\begin{array}{l}\text { Allometric - } \\
\text { Allometric + }\end{array}$ \\
\hline D. trunculus ${ }^{5}(0.5-1 \mathrm{~m})$ & 1975 & $\begin{aligned} & 25.08 \pm 4.69 \\
&(8.91-40.03)\end{aligned}$ & $\mathrm{W} / \mathrm{L}$ & $\mathrm{W}=0.0003 \mathrm{~L}^{2.69}$ & 0.96 & $0.012(2.67-2.72)$ & Allometric - \\
\hline D. trunculus ${ }^{5}(1.5-2.0 \mathrm{~m})$ & 1167 & $\begin{array}{c}25.71 \pm 5.28 \\
(11.88-41.14)\end{array}$ & $\mathrm{W} / \mathrm{L}$ & $\mathrm{W}=0.0003 \mathrm{~L}^{2.75}$ & 0.94 & $0.020(2.71-2.79)$ & Allometric - \\
\hline D. trunculus $^{5}(3.0-6 \mathrm{~m})$ & 2917 & $\begin{array}{l}28.55 \pm 5.22 \\
(10.40-44.27)\end{array}$ & $\mathrm{W} / \mathrm{L}$ & $\mathrm{W}=0.0004 \mathrm{~L}^{2.70}$ & 0.95 & $0.011(2.68-2.72)$ & Allometric - \\
\hline \multirow[t]{2}{*}{ D. trunculus ${ }^{5}(0.5-1 \mathrm{~m})$} & - & - & $\mathrm{H} / \mathrm{L}$ & $\mathrm{H}=0.822 \mathrm{~L} 0.88$ & 0.96 & $0.004(0.874-0.889)$ & Allometric - \\
\hline & & & $\mathrm{Wd} / \mathrm{L}$ & $\mathrm{Wd}=0.221 \mathrm{~L} 1.12$ & 0.91 & $0.008(1.104-1.135)$ & Allometric + \\
\hline \multirow[t]{2}{*}{ D. trunculus $^{5}(1.5-2 \mathrm{~m})$} & - & - & $\mathrm{H} / \mathrm{L}$ & $\mathrm{H}=0.800 \mathrm{~L} 0.88$ & 0.96 & $0.005(0.879-0.898)$ & Allometric - \\
\hline & & & $\mathrm{Wd} / \mathrm{L}$ & $\mathrm{Wd}=0.250 \mathrm{~L} 1.07$ & 0.90 & $0.011(1.057-1.099)$ & Allometric + \\
\hline \multirow[t]{2}{*}{ D. trunculus ${ }^{5}(3.0-6 \mathrm{~m})$} & - & - & $\mathrm{H} / \mathrm{L}$ & $\mathrm{H}=0.780 \mathrm{~L} 0.89$ & 0.97 & $0.003(0.892-0.903)$ & Allometric - \\
\hline & & & $\mathrm{Wd} / \mathrm{L}$ & $\mathrm{Wd}=0.326 \mathrm{~L} 0.99$ & 0.91 & $0.006(0.987-1.010)$ & Isometric \\
\hline \multirow[t]{3}{*}{ D. striatus 6} & 282 & $13.11 \pm 5.26$ & $\mathrm{H} / \mathrm{L}$ & $\mathrm{H}=-0.182+0.98 \mathrm{~L}$ & 0.99 & 0.005 & Allometric - \\
\hline & & $(3.48-28.24)$ & $\mathrm{Wd} / \mathrm{L}$ & $\mathrm{Wd}=-0.549+1.13 \mathrm{~L}$ & 0.98 & 0.009 & Allometric + \\
\hline & & & $\mathrm{Wd} / \mathrm{H}$ & $\mathrm{Wd}=-0.340+1.14 \mathrm{~A}$ & 0.98 & 0.007 & Allometric + \\
\hline \multirow[t]{3}{*}{ D. denticulatus 6} & 285 & $15.62 \pm 5.77$ & $\mathrm{H} / \mathrm{L}$ & $\mathrm{H}=-0.178+1.005 \mathrm{~L}$ & 0.99 & 0.003 & Isometric \\
\hline & & $(3.94-24.39)$ & $\mathrm{Wd} / \mathrm{L}$ & $\mathrm{Wd}=-0.435+1.028 \mathrm{~L}$ & 0.98 & 0.006 & Allometric + \\
\hline & & & $\mathrm{Wd} / \mathrm{H}$ & $\mathrm{Wd}=-0.252+1.022 \mathrm{~A}$ & 0.99 & 0.006 & Allometric + \\
\hline
\end{tabular}

over a long period of sampling (Herrmann et al., 2009). In the study area, the collected individuals mainly comprised recruited and juvenile clams, with smallsized adults $(<26 \mathrm{~mm})$ collected at a lower proportion. The use of an empty shell collected in the same beach is a useful reference of the maximum expected size ( 39 $\mathrm{mm}$ ) for the clam population in the intertidal environment. However, the estimated maximum $\mathrm{L}$ value was still lower $(29.16 \mathrm{~mm})$.

The growth values estimated in previous studies of donacids contrast with those obtained in this study (Table 6). There are dissimilarities in the estimates, even among populations of the same species and from the same study area (e.g., D. trunculus or $D$. hanleyanus), as a result of the use of different methods. For this reason, it is important to recognize inconsistencies related to methodology and differentiate these from variation attributable to natural causes. The values of $\mathrm{L}_{\infty}$ and $\mathrm{K}$ obtained in the present study indicate that D. punctatostriatus presents smaller sizes than those observed in other species of Donax from temperate waters (Table 6).

According to Ansell (1983), mortality rates are high in donacids of tropical latitudes. Mortality in $D$. punctatostriatus estimated using the method of Beverton and Holt, as well as those of Ault and Erhardt and Pauly, provide a range of values. The value obtained with the Beverton and Holt method seems to be overestimated $\left(1.15 \mathrm{yr}^{-1}\right)$, because it was designed to estimate fish mortality. On the other hand, the methods of Ault and Erhardt, and Pauly, were consistent in their mortality values $\left(0.84\right.$ and $\left.0.88 \mathrm{yr}^{-1}\right)$; both methods have been more frequently used to estimate mortality in invertebrates, including bivalves (Sparre \& Venema, 1995). 
Table 6. Growth parameters estimated with different methods in species of the genus Donax. *in situ fluorescent marking (IFM) method.

\begin{tabular}{|c|c|c|c|c|c|c|}
\hline Species & Region & $\begin{array}{c}\text { Maximum } \\
\text { length }(\mathrm{mm})\end{array}$ & Method & $\begin{array}{l}\mathrm{K} \\
\left(\mathrm{yr}^{-1}\right)\end{array}$ & $\mathrm{L}_{\infty}(\mathrm{mm})$ & Reference \\
\hline Donax variabilis roemeri & Tuxpan, Veracruz, Mexico & 24 & Modal progression & 0.520 & 37.8 & $\begin{array}{l}\text { Belmar Pérez \& Guzmán } \\
\text { del Próo (1995) }\end{array}$ \\
\hline Donax trunculus & West coast Spain & 36 & Growth rings & 0.71 & 41.8 & Ramón et al. (1995) \\
\hline Donax trunculus & West coast Spain & 36 & $\begin{array}{l}\text { Length frequency } \\
\text { distribution }\end{array}$ & 0.58 & 46.0 & Ramón et al. (1995) \\
\hline Donax trunculus & South coast Portugal & 44 & Growth rings & 0.58 & 47.3 & Gaspar et al. (1999) \\
\hline Donax dentifer & Málaga Bay, Colombia & 30.5 & Mark-recapture & 0.624 & 29.3 & Riascos \& Urban (2002) \\
\hline Donax serra & Namibian coast & 82 & Mark-recapture & 0.274 & 82 & Laudien et al. (2003) \\
\hline Donax denticulus & $\begin{array}{l}\text { Ensenada La Guardia, } \\
\text { Venezuela }\end{array}$ & 30 & Modal progression & 1.79 & 30.0 & Marcano et al. (2003) \\
\hline Donax obesulus & Sarapampa, Perú & 31 & $\begin{array}{l}\text { Length frequency } \\
\text { distribution }\end{array}$ & 0.991 & 33.7 & $\begin{array}{l}\text { Aguirre-Velarde \& Mendo- } \\
\text { Aguilar (2008) }\end{array}$ \\
\hline Donax hanleyanus & $\begin{array}{l}\text { Mar de Las Pampas, Province } \\
\text { of Buenos Aires, Argentina }\end{array}$ & 44 & IFM* & 0.410 & 44 & Herrmann et al. (2009) \\
\hline Donax hanleyanus & $\begin{array}{l}\text { Mar de las Pampas, Province } \\
\text { of Buenos Aires, Argentina }\end{array}$ & 40 & $\begin{array}{l}\text { Length frequency } \\
\text { distribution }\end{array}$ & 0.470 & 44 & Herrmann et al. (2009) \\
\hline Donax hanleyanus & $\begin{array}{l}\text { Faro Querandí, Atlantic coast, } \\
\text { Argentina }\end{array}$ & 40 & $\begin{array}{l}\text { Length frequency } \\
\text { distribution }\end{array}$ & 0.480 & 44 & Herrmann et al. (2009) \\
\hline Donax punctatostriatus & $\begin{array}{l}\text { Isla de La Piedra, Sinaloa, } \\
\text { Mexico }\end{array}$ & 25.64 & $\begin{array}{l}\text { Length frequency } \\
\text { distribution }\end{array}$ & 0.430 & 39 & Present study \\
\hline
\end{tabular}

At present, only some authors have recorded the mortality of donacids. According to Riascos \& Urban (2002), the mortality of $D$. dentifer in Colombia shows that the populations of the lower part of the intertidal zone are composed of small $(2-5 \mathrm{~mm})$ individuals with a mortality of $2.6 \mathrm{yr}^{-1}$, while the larger $(19-25 \mathrm{~mm})$ individuals present a rate of $1.7 \mathrm{yr}^{-1}$. The small clams found in the low part of the intertidal zone are reported to be more vulnerable to depredation by birds and crabs (Soares et al., 1996, Riascos \& Urban, 2002), which could explain the high mortality prevalent in this zone.

The sandy beach of Isla de La Piedra is semiprotected, with a strong influence of the waves and tides; it is a very dynamic, high-energy beach with significant turnover of sediments throughout the year (Montaño-Ley, 1985). The compressed form of the $D$. punctatostriatus shell enables individuals of this species to tunnel more rapidly into the sediment and avoid being removed from the substrate by the waves and currents. The negative allometry recorded in $\mathrm{L} / \mathrm{W}$, $\mathrm{L} / \mathrm{Wd}$ and $\mathrm{H} / \mathrm{W}$ in the present study supports this hypothesis. However, the mortality of this species, which is lower than that recorded for $D$. dentifer by Riascos \& Urban (2002), can be explained by the fact that the former species can bury itself much more rapidly and escape possible depredation.

The bivalves exhibit wide morphological variation, which is intimately linked to their life cycle and ecology. It is possible to determine which environmental variables influence the growth and form of the shells of this group of mollusks. The methods used in the present study are only an approximation to the real growth and mortality values of the population of the Isla de La Piedra bean clam. According to these values, this population has a relatively rapid growth rate and moderate mortality compared to populations of other species.

The majority of the marine mollusks of economic importance are distributed in the coastal zones, including the sandy and rocky beaches, and the estuaries and coastal lagoons. Mexico presents very favorable conditions for the exploitation of mollusks since its coastline is more than $10,000 \mathrm{~km}$ long (RuizDurá, 1985). However, a problem for adequate exploitation of these mollusks in Mexico is the scarcity of published information on their biology and ecology. Due to the intense exploitation of the main fishing resources traditionally exploited, and the evident decrease of their populations, other species of potential importance are currently considered as a real alternative, which is the case of several clam species of moderate and small sizes with significant populations in specific locations. Exploitation alternatives involve the assessment of their population structure and dynamics for sustainable use.

Although there is relevant information on other species of Donax from different populations of the world, there is little knowledge on the biology and ecology of the bean clam $D$. punctatostriatus. The population of Isla de La Piedra is of particular interest 
since it is located on the northern limit of its geographical distribution, in a subtropical region located at the mouth of the Gulf of California, where environmental conditions should have substantial influence, in particular, the temperature and the photoperiod. For example, information on reproductive biology will help understand the strategies of development and survival in this part of the world.

\section{ACKNOWLEDGMENTS}

We are grateful to Carlos Sauma, Eva Visueta, María Ana Tovar, and Paul Esqueda for their help during fieldwork. The second author thanks the Consejo Nacional de Ciencias y Tecnología for financial support (Ph.D. scholarship number 90606). The research was held at the Centro Universitario de Ciencias Biológicas y Agropecuarias at Universidad of Guadalajara.

\section{REFERENCES}

Aguirre-Velarde, A. \& Mendo-Aguilar, J. 2008. Crecimiento y producción de Donax obesulus Reeve, 1854 (Bivalvia: Donacidae) en playa Sarapampa, Asia, Lima. Ecología Aplicada, 7(1-2): 63-70.

Ansell, A.D. 1983. The biology of the genus Donax. In: McLachlan, A. \& Erasmus, T. (Eds.). Developments in hydrobiology: sandy beaches as ecosystems. Junk Publishers, The Hague, pp. 607-635.

Ault, J.S. \& Erhardt, N.M. 1991. Correction to the Beverton and Holt Z-estimator for truncate catch length-frequency. ICLARM Fishbyte, 9(1): 37-39.

Belmar-Pérez, J. \& Guzmán del Próo, S.A. 1997. Reproducción y crecimiento de la almeja Donax variabilis roemeri, en la barra norte de Tuxpan, Veracruz, México (1994-1995). In: Farfán, C. (Ed.). III Congreso Latinoamericano de Malacología y VI Reunión Nacional de Malacología y Conquiliología. Centro de Investigación Científica y Educación Superior de Ensenada, Ensenada.

Beverton, R.J.H. \& Holt, S.J. 1956. The theory of fishing. In: Graham, M. (Ed.). Sea fisheries: their investigation in the United Kingdom. Arnold, London.

Brown, A.C. \& Trueman, E.R. 1991. Burrowing of sandybeach mollusks in relation to penetrability of the substratum. Journal of Molluscan Studies, 57: 134136.

Caill-Milly, N., Bru, N., Mahé, K., Borie, C. \& D’Amico, F. 2012. Shell shape analysis and spatial allometry patterns of Manila clam (Ruditapes philippinarum) in a mesotidal coastal lagoon. Journal of Marine Biology, 2012: 1-11. doi: 10.1155/2012/281206.
Coan, E.V. \& Valentich-Scott, P. 2012. Bivalve seashells of tropical West America. Marine bivalve mollusks from Baja California to northern Perú. Santa Barbara Museum of Natural History, Santa Barbara.

De la Huz, R., Rastra, M. \& López, J. 2002. The influence of sediment grain size on burrowing, growth, and metabolism of Donax trunculus L. (Bivalvia: Donacidae). Journal of Sea Research, 47: 85-95.

Ebert, T.A. 1988. Latitudinal variation in size structure of the west coast purple sea urchin: a correlation with headlands. Limnology and Oceanography, 33(2): 286294.

Esqueda-González, M.C., Ríos-Jara, E., López-Uriarte, E., Chávez-Sánchez, M.C., Abad-Rosales, S.M. \& Michel-Morfín, J.E. 2018. Reproductive cycle of Donax punctatostriatus (Hanley, 1843) (Bivalvia: Donacidae) in a sandy beach of Sinaloa, Mexico. American Malacological Bulletin, 36(2): 1-12.

Fiori, S.M. \& Carcedo, M.C. 2015. Influence of grain size on burrowing and alongshore distribution of the yellow clam (Amarilladesma mactroides). Journal of Shellfish Research, 34(3): 785-789. doi: 10.2983/035.034.0307

Gaspar, M.B., Ferreira, R. \& Monteiro, C.C. 1999. Growth and reproductive cycle of Donax trunculus L., (Mollusca: Bivalvia) off Faro, southern Portugal. Fisheries Research, 41: 309-319.

Gaspar, M.B., Santos, M.N. \& Vasconcelos, P. 2001. Weight-lenght relationships of 25 bivalve species (Mollusca: Bivalvia) from the Algarve coast (southern Portugal). Journal of the Marine Biological Association of the United Kingdom, 81: 805-807.

Gaspar, M.B., Santos, M.N., Vasconcelos, P. \& Monteiro, C.C. 2002a. Shell morphometric relationships of the most common bivalve species (Mollusca: Bivalvia) of the Algarve coast (southern Portugal). Hydrobiologia, 477: 73-80.

Gaspar, M.B., Chícharo, L.M., Vasconcelos, P., García, A., Santos, A.R. \& Monteiro, C.C. 2002b. Depth segregation phenomenon in Donax trunculus (Bivalvia: Donacidae) populations of the Algarve coast (southern Portugal). Scientia Marina, 66(2): 111121.

Gayanilo Jr., F.C., Sparre, P. \& Pauly, D. 2005. The FAOICLARM stock assessment tools II (FiSAT II). User guide. FAO computerized information series (Fisheries) 8, Rome.

Herrmann, M., Lepore, M.L., Laudien, J., Arntz, W.E. \& Penchaszadeh, P.E. 2009. Growth estimations of the Argentinean wedge clam Donax hanleyanus: a comparison between length-frequency distribution and size-increment analysis. Journal of Experimental Marine Biology and Ecology, 379: 8-15.

Hinch, S.G. \& Bailey, R.C. 1988. Within and among lake variation in shell morphology of the freshwater clam 
Elliptio complanata (Bivalvia: Unionidae) from southcentral Ontario lakes. Hydrobiologia, 157: 27-32.

Jaramillo, E., Contreras, H. \& Duarte, C. 2007. Community structure of the macroinfauna inhabiting tidal flats characterized by the presence of different species of burrowing bivalves in southern Chile. Hydrobiologia, 580: 85-96.

Laudien, J., Brey, T. \& Arntz, W.E. 2003. Population structure, growth, and production of the surf clam Donax serra (Bivalvia, Donacidae) on two Namibian sandy beaches. Estuarine, Coastal, and Shelf Science, 58S: 105-115. doi: 10.1016/S0272-7714(03)00044-1.

Laxmilatha, P. 2008. Biometric relationships of Mactra violacea (Gmelin) from Kerala, south-west coast of India. Indian Journal Fisheries, 55(4): 349-351.

Laws, E.A. \& Archie, J.W. 1981. Appropriate use of regression analysis in marine biology. Marine Biology, 65: 13-16.

Le Cren, E.D. 1951. The length-weight relationship and seasonal cycle in gonad weight and condition in the perch (Perca fluviatilis). Journal of Animal Ecology, 20(2): 201-219.

Levinton, J.S. 2001. Marine biology. Function, biodiversity, ecology. Oxford University Press, Oxford.

Marcano, J.S., Prieto, A., Larez, A. \& Salazar, H. 2003. Crecimiento de Donax denticulatus (Linné 1758) (Bivalvia: Donacidae) en la ensenada La Guardia, Isla de Margarita, Venezuela. Zootecnia Tropical, 21(3).

Mazé, R.A. \& Laborda, A.J. 1990. Cambios estacionales de una población de Donax trunculus (Linnaeus, 1758) (Pelecypoda: Donacidae) en la ría de El Barquero (Lugo, NO. de España). Scientia Marina, 54(2): 131138.

McLachlan, A. 1996. Physical factors in benthic ecology: effects of changing sand particle size on beach fauna. Marine Ecology Progress Series, 131: 205-217.

McLachlan, A., Jaramillo, E., Defeo, O., Dugan, J., de Ruyck, A. \& Coetzee, P. 1995. Adaptations of bivalves to different beach types. Journal of Experimental Marine Biology and Ecology, 187: 147-160.

Montaño-Ley, Y. 1985. Estudios del transporte litoral de arenas en la Isla de la Piedra, Mazatlán, Sinaloa, usando trazadores fluorescentes. Anales del Instituto de Ciencias del Mar y Limnología, Universidad Nacional Autónoma de México, 12: 15-32.

Nel, R., McLachlan, A. \& Winter, D.P.E. 2001. The effect of grain size on the burrowing of two Donax species. Journal of Experimental Marine Biology and Ecology, 265: 219-238.

Received: 12 July 2018; Accepted: 10 June 2019
Neuberger-Cywiak, L., Achituv, Y. \& Mizrahi, L. 1990. The ecology of Donax trunculus Linnaeus and Donax semistriatus Poli from the Mediterranean coast of Israel. Journal of Experimental Marine Biology and Ecology, 134: 203-220.

Newell, C.R. \& Hidu, H. 1982. The effects of sediment type on growth rate and shell allometry in the softshelled clam Mya arenaria L. Journal of Experimental Marine Biology and Ecology, 65: 285-295.

Ocaña, F.A. \& Fernández, A. 2011. Morfometría de la concha de Donax denticulatus y Donax striatus de dos playas de Cuba Oriental. Revista Marina Costera, 3: 67-75.

Ramón, M., Abelló, P. \& Richardson, C.A. 1995. Population structure and growth of Donax trunculus (Bivalvia: Donacidae) in the western Mediterranean. Marine Biology, 121: 665-671.

Riascos, J.M. \& Urban, H.J. 2002. Dinámica poblacional de Donax dentifer (Veneroida: Donacidae) en Bahía Málaga, Pacífico Colombiano durante el fenómeno "El Niño" 1997/1998. International Journal of Tropical Biology and Conservation, 50(3-4): 1113-1123.

Rhoads, D.C. \& Pannella, G. 1970. The use of molluscan growth patterns in ecology and paleoecology. Lethaia, 3: 143-161.

Ricker, W.E. 1973. Linear regressions in fishery research. Journal of the Fisheries Research Board of Canada, 30: 409-434.

Ruiz-Durá, M.F. 1985. Recursos pesqueros de las costas de México. Limusa, México D.F.

Sastre, M.P. 1984. Relationships between environmental factors and Donax denticulatus populations in Puerto Rico. Estuarine Coastal, and Shelf Science, 19: 217230.

Soares, A.G., McLachlan, A. \& Schlacher, T.A. 1996. Disturbance effects of stranded kelp on populations of the sandy beach bivalve Donax serra (Röding). Journal of Experimental Marine Biology and Ecology, 205: 165-186.

Sokal, R.R. \& Rohlf, F.J. 1995. Biometry: the principles and practice of statistics in biological research. W.H. Freeman, New York.

Sparre, P. \& Venema, S.C. 1995. Introducción a la evaluación de recursos pesqueros tropicales. Parte 1. Manual. Organización de las Naciones Unidas para la Agricultura y la Alimentación, Valparaíso.

Thayer, C.W. 1975. Morphological adaptations of benthic invertebrates to soft substrata. Journal of Marine Research, 33: 177-189.

Trueman, E.R., Brand, A.R. \& Davis, P. 1966. The effect of substrate and shell shape on the burrowing of some common bivalves. Proceedings of the Malacological Society of London, 37: 97-109. 